UDC: $577.35+577.352+576.311$

\title{
EFFECT OF NOVEL 2-AMINO-5-BENZYLTHIAZOLE DERIVATIVE ON CELLULAR ULTRASTRUCTURE AND ACTIVITY OF ANTIOXIDANT SYSTEM IN MURINE LYMPHOMA CELLS
}

\author{
Ya. R. Shalai', M. V. Popovych', O. R. Kulachkovskyy', \\ V. P. Hreniukh', S. M. Mandzynets ${ }^{1}$, N. S. Finiuk ${ }^{1,2}$, A. M. Babsky ${ }^{1}$ \\ ${ }^{1}$ Ivan Franko National University of Lviv, Biology Faculty, 4, Hrushevskyi St., Lviv 79005, Ukraine \\ e-mail: yarunash@gmail.com \\ 2 Institute of Cell Biology, NAS of Ukraine, 14-16, Drahomanov St., Lviv 79005, Ukraine
}

Shalai Ya.R., Popovych M.V., Kulachkovskyy O.R., Hreniukh V.P., Mandzynets S.M., Finiuk N.S., Babsky A.M. Effect of novel 2-amino-5-benzylthiazole derivative on cellular ultrastructure and activity of antioxidant system in murine lymphoma cells. Studia Biologica, 2019: 13(1); 51-60 • DOI: https://doi.org/10.30970/sbi.1301.591

The influence of newly synthesized thiazole derivative $\mathrm{N}$-(5-benzyl-1,3-thiazol2-yl)-3,5-dimethyl-1-benzofuran-2-carboxamide on cellular ultrastructure and antioxidant system activity in lymphoma cells was studied in vitro. A pronounced cytotoxic action of the newly synthesized thiazole derivative on the tumor cells in vitro was reported earlier. However, no cytotoxicity of this substance was detected toward noncancerous cells. In addition, it was shown that the scavengers of active forms of Oxygen significantly reduced a cytotoxic effect of the studied compound. It was found that thiazole derivatives at concentrations of 10 and $50 \mu \mathrm{M}$ affected the level of lipid peroxidation products and superoxide radicals. The purpose of this work was to investigate the effect of N-(5-benzyl-1,3-thiazol-2-yl)-3,5-dimethyl-1-benzofuran-2-carboxamide on the ultrastructure of lymphoma cells and the activity of enzymes of the antioxidant defense.

The influence of the thiazole derivatives on cellular ultrastructure of lymphoma cells was investigated. Electron microscopy study show that control lymphoma cells have a special subcellular formations such as a relatively large nucleus, and specific plasma membrane filaments. The effects of thiazole derivative at concentrations of 10 and $50 \mu \mathrm{M}$ revealed apoptotic and necrotic manifestations of cytotoxicity, such as a deformation and disintegration of nucleus, an increased area and number of lysosomes, a destruction of the plasma membrane and a change of mitochondria shape.

The effect of the thiazole derivative on the activity of key enzymes of the antioxidant system in lymphoma cells was investigated. The studied compound at concentrations of

(C) 2019 Ya. R. Shalai et al.; Published by the Ivan Franko National University of Lviv on behalf of Біологічні Студії / Studia Biologica. This is an Open Access article distributed under the terms of the Creative Commons Attribution License (http://www.budapestopenaccessinitiative.org/ and Creative Commons Attribution 4.0 License), which permits unrestricted reuse, distribution, and reproduction in any medium, provided the original work is properly cited.

ISSN 1996-4536 (print) • ISSN 2311-0783 (on-line) • Біологічні Студії / Studia Biologica • 2019 • Том 13/№1 • С. 51-60 
10 and $50 \mu \mathrm{M}$ activate superoxide dismutase and lead to a decrease of the activity of catalase and glutathione peroxidase. This effect suggests that the change in the activity of enzymes leads to accumulation of $\mathrm{H}_{2} \mathrm{O}_{2}$ in the lymphoma cells. Such results indicate that the studied substance can realize its cytotoxic effect through the action of the antioxidant system. The obtained data can be used to carry out further preclinical studies of the thiazole derivatives as potential antitumor drugs.

Keywords: lymphoma, thiazole derivative, cellular ultrastructure, antioxidant system, lysosomes

\section{INTRODUCTION}

Intracellular structure reflects the physiological condition in cells. The ultrastructure investigations detected the effect of damaging factors on different components of the cell. Electron microscopy along with the study of functional processes makes it possible to establish cause-effect relationships between different pathological conditions and ultrastructural changes in the cell [16]. Pathological states in the organism can be conditioned to distortion of the oxidative-reducing homeostasis. Under these conditions, the ratio of formation of free radicals and the activity of enzymes of antioxidant defense is often distorted [9]. Various factors such as antitumor drugs may affect this ratio.

The thiazole derivatives are heterocyclic compounds that exhibit in addition to antitumor activity also antibacterial, antifungal, antiviral, anti-inflammatory, anticonvulsant, and antidepressant activities [11, 14, 15]. A cytotoxic effect of newly synthesized thiazole derivatives on some lines of tumor cells has been established [1,2]. It was found that scavengers of the reactive Oxygen species (ROS) significantly reduced a cytotoxic effect of the investigated substances [2]. Further investigations of lymphoma cells revealed that the levels of lipid peroxidation and superoxide radicals were affected by the thiazole derivatives [12]. The purpose of this work was to investigate the effect of thiazole derivative (TD: N-(5-benzyl-1,3-thiazol-2-yl)-3,5-dimethyl-1-benzofuran-2-carboxamide) on the ultrastructure of lymphoma cells and the activity of enzymes of the antioxidant defense.

\section{MATERIALS AND METHODS}

Experiments were conducted using white wild-type male mice (20-30 g) with grafted NK/Ly lymphoma. Animals were kept in standard vivarium conditions at constant temperature on a mixed ration. All manipulations with animals were conducted in accordance with "General Ethical Principles of Experimentation on Animals" approved by the First National Congress on Bioethics (Kyiv, Ukraine, 2001) and "European Convention for the Protection of Vertebrate Animals used for Experimental and Other Scientific Purposes" (Strasbourg, France, 1985). The bioethical examination of the experiments carried out at the Biological Faculty of Ivan Franko National University of Lviv was executed according to a protocol No. 10042019 of April 1, 2019.

Ascites tumor cells were passaged by intraperitoneal inoculation of $10-15 \times 10^{6}$ cells to mice. Ascite was drained from the abdominal cavity of anaesthetized mice with sterile syringe on 7-10 day after the inoculation. Lymphoma cells were washed in $0.2 \mathrm{~mol} / \mathrm{L}$ cacodylate buffer and fixed in a solution containing $1.5 \%$ glutaraldehyde in the cacodylate buffer for $2 \mathrm{~h}$ and $1 \%$ solution of osmium tetroxide $(2 \mathrm{~h})$ in the same buffer. Subsequently, the specimens were transferred in a $1.5 \%$ aqueous uranyl acetate solution

ISSN 1996-4536 (print) • ISSN 2311-0783 (on-line) • Біологічні Студії / Studia Biologica • 2019 • Том 13/№1 • С. 51-60 
for 12 h. Fixed specimens were washed and dehydrated at room temperature at concentrations of ethanol from 70 to $100 \%$. The dehydrated specimens were placed in a pure epoxy resin for $48 \mathrm{~h}$ at 40 and $60^{\circ} \mathrm{C}$. Microscopic sections were cut on a UTMP6 ultramicrotome; then, the specimens were contrasted with a $1.5 \%$ solution of uranylacetate (prepared in 70\% ethanol) and photographed using a PEM100 transmission electron microscope (Electron-SELMI, Ukraine) [4].

The thiazole derivative was synthesized at the Department of Organic Chemistry of Ivan Franko National University of Lviv. The steps of synthesis were described in detail in our previous publication [1].

The thiazole derivative was dissolved in the dimethylsulfoxide DMSO (final concentration 5\%) and was added to the lymphoma homogenate at a final concentrations of 1, 10 and $50 \mu \mathrm{M}$ duration of incubation $10 \mathrm{~min}$.

To measure the activity of enzymes, lymphoma cell samples were frozen in a freezer chamber to $-20^{\circ} \mathrm{C}$ and subsequently used for investigation. Superoxide dismutase activity was measured by the method described by V. Kostyuk et al. [6]. The activity of SOD was expressed as unit SOD / mg protein. Catalase activity was measured spectrophotometrically by the method described by $\mathrm{M}$. Korolyuk et al. [5] for an absorption wave length of $410 \mathrm{~nm}$. The enzymatic activity was expressed in nmoles of $\mathrm{H}_{2} \mathrm{O}_{2} / \mathrm{min} \times \mathrm{mg}$ of protein. Glutathionperoxidase (GPO) activity was measured by the method of Moin [10]. The enzymatic activity was expressed in $\mu \mathrm{M}$ of $\mathrm{G}-\mathrm{SH} / \mathrm{min} \times \mathrm{mg}$ of protein. Protein concentration in each specimen was determined by the method of O. Lowry et al. [7].

On the basis of electronic microphotographs, the following data were calculated: the relation of the nucleus and cytoplasm area, the ratio of the area of nucleus and cytoplasm (N/C ratio), a number and area of mitochondria, a number and area of lysosomes, as well as a qualitative assessment of the form of cells, nuclei, mitochondria and their christs.

Statistical analysis of the obtained results was carried out using the MS Excel-2013 program. To assess a reliability of difference between statistical characteristics of two alternative sets of data, Student's coefficient was calculated. The difference was found to be significant at $P<0.05$.

\section{RESULTS AND DISCUSSION}

Qualitative analysis of pictures of control lymphoma NK/Ly cells showed that nucleus (1) takes up a large part ( $40 \%)$ of the cell area (Fig. 1). High nucleus-cytoplasm ratio is typical for tumor cells where an intensive synthetic and proliferative processes occur. Well notable nucleolus (3) and mitochondria (4) of different sizes and shapes are presented. The mitochondrial matrix is electronically dense. The plasma membrane contains the filamentary looking buds (6) that, most likely, play an important role in adhesion with other cells (Fig. 1, B) or with surfaces. In addition, there are a number of high-density lysosomes localized in the cytoplasm (5) (Fig. 1).

It was established that TD at concentration of $10 \mu \mathrm{M}$ causes destructive changes in lymphoma cells mainly via apoptosis (Fig. 2). In particular, the cells decreased their size (shrinkage) and lost their elliptical shape. We observed a deformation of the nucleus, a decrease in their size (A1, B1, D1), and a destruction of plasma membrane (A7, C7, D7). Some mitochondria contain swollen crists (B4), while other contain paralleled crists (D4).

TD at $50 \mu \mathrm{M}$ concentration caused even more destructive changes in the lymphoma cells through both apoptosis and necrosis (Fig. 3). Some cells shrinked (B and C) and lost

ISSN 1996-4536 (print) • ISSN 2311-0783 (on-line) • Біологічні Студії / Studia Biologica • 2019 • Том 13/№1 • С. 51-60 

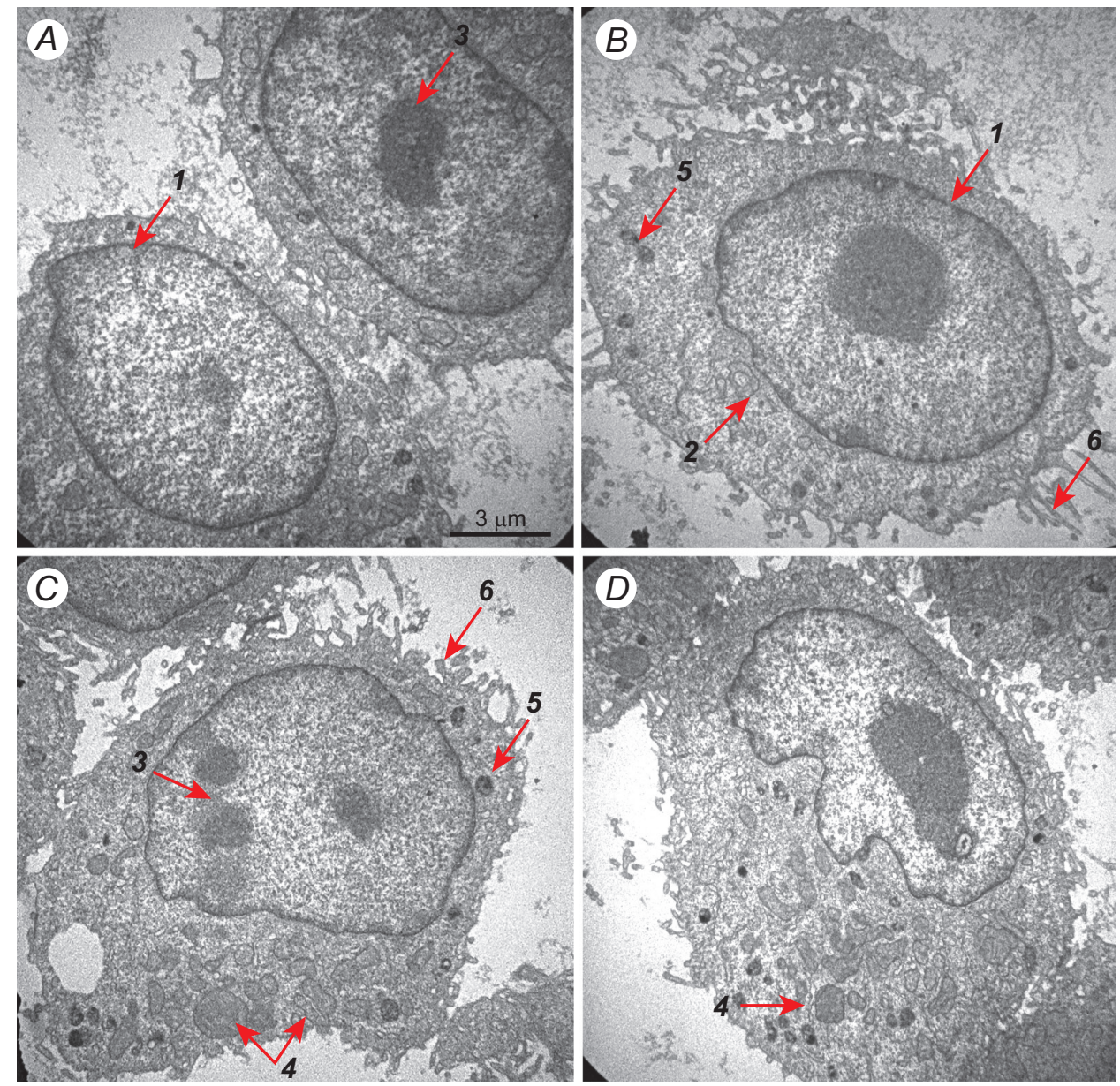

Fig. 1. Electronic microscopy of lymphoma NK/Ly untreated cells. The arrows point to: 1 - nucleus; 2 - cytoplasm; 3 - nucleolus; 4 - mitochondria; 5 - lysosomes; 6 - buds of the plasma membrane

Рис. 1. Електронна мікроскопія клітин лімфоми NK/Ly (контроль). Стрілками позначено: 1 - ядро; 2 цитоплазма; 3 - ядерце; 4 - мітохондрії; 5 - лізосоми; 6 - вип'ячування плазматичної мембрани

their elliptical shape, while other cells swell (A and D). Many other cells demonstrate a destruction such as a deformation of the nucleus $(B, 1$ and $D, 1)$, a damage of plasma membrane (B, C), and an increase in number of lysosomes (A, D, 5) (Fig. 3).

Quantitative analysis of the electronic pictures showed that N/C ratio in control lymphoma NK/Ly cells was 0.69 relative units (r. u.). Under the effect of studied compound at concentrations of 10 and $50 \mu \mathrm{M}$, the N/C ratio was decreased by 21 and $23 \%$, respectively, however, a significance of these changes was low $(P>0.05)$. A number of lysosomes increased by $60 \%(50 \mu \mathrm{M}$ TD), while their area was increased by $28 \%$ $(10 \mu \mathrm{M}, P<0.05)$ and $53 \%(50 \mu \mathrm{M}, P<0.01)$, respectively. The lysosomes act as the waste disposal system of the cell by digesting unwanted materials in a cytoplasm using hydrolytic enzymes. The number and area of mitochondria did not significantly change (Table).

Thus, the results of the electronic microscopy show that control cells of lymphoma have a typical shape of tumor cells: large nucleus, less amount of cytoplasm, specific

ISSN 1996-4536 (print) • ISSN 2311-0783 (on-line) • Біологічні Студії / Studia Biologica • 2019 • Том 13/№1 • C. 51-60 

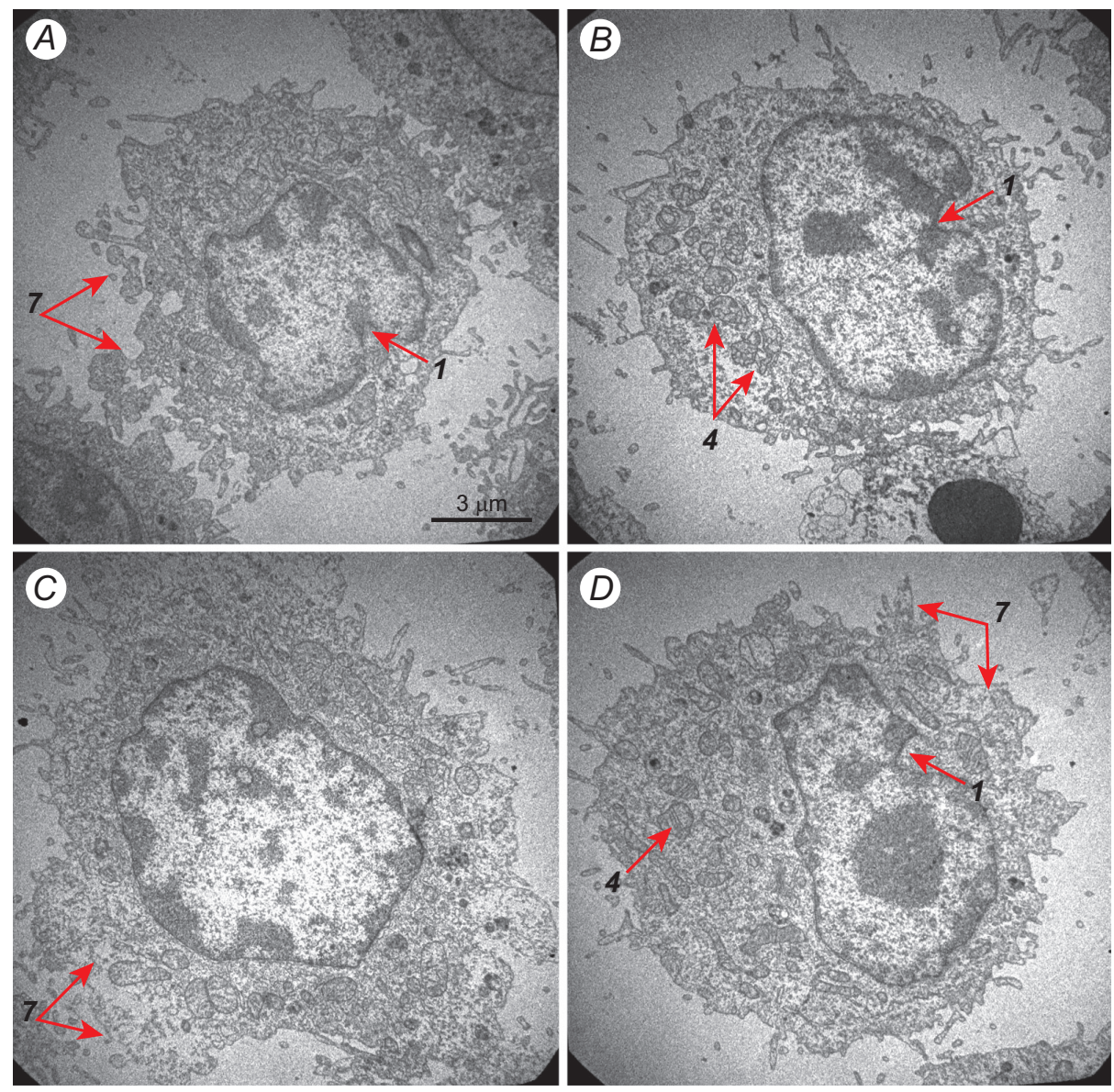

Fig. 2. Electronic microscopy of NK/Ly lymphoma cells under the effect of the thiazole derivative at concentration of $10 \mu \mathrm{M}$. For further description, see in Fig. 1

Рис. 2. Електронна мікроскопія клітин лімфоми NK/Ly за дії похідного тіазолу в концентрації 10 мкM. Інші пояснення див. рис. 1

plasma membrane buds, etc. The effects of TD revealed both the apoptotic and necrotic manifestations of cytotoxicity: a deformation and a disintegration of the nucleus, a destruction of plasma membrane, a significant increase in area and number of lysosomes, etc.

The thiazole derivative may realize their cytotoxic effect through the effect on the antioxidant system activity [2,12]. Since the level of lipid peroxidation and radicals is regulated by the activity of antioxidant enzymes, the second task of our work was to find out what is the effect of the newly synthesized TD on the activity of key enzymes of the antioxidant system in lymphoma cells.

Superoxide dismutase is one of key enzyme of the antioxidant protection in the cell. Its main function is the dissociation of $\mathrm{O}_{2}^{--}$to the Hydrogen peroxide that is reduced by the catalase or by the glutathione peroxidase.

The control level of SOD activity in lymphoma was $0.32-0.37$ active units/min $\times \mathrm{mg}$ of protein. Under the effect of TD during 15 min at concentrations of 10 and $50 \mu \mathrm{M}$, the activity of SOD increased by $35 \%(P<0.01)$ and $29 \%(P<0.05)$, respectively (Fig. 4).

ISSN 1996-4536 (print) • ISSN 2311-0783 (on-line) • Біологічні Студії / Studia Biologica • 2019 • Том 13/№1 • С. 51-60 

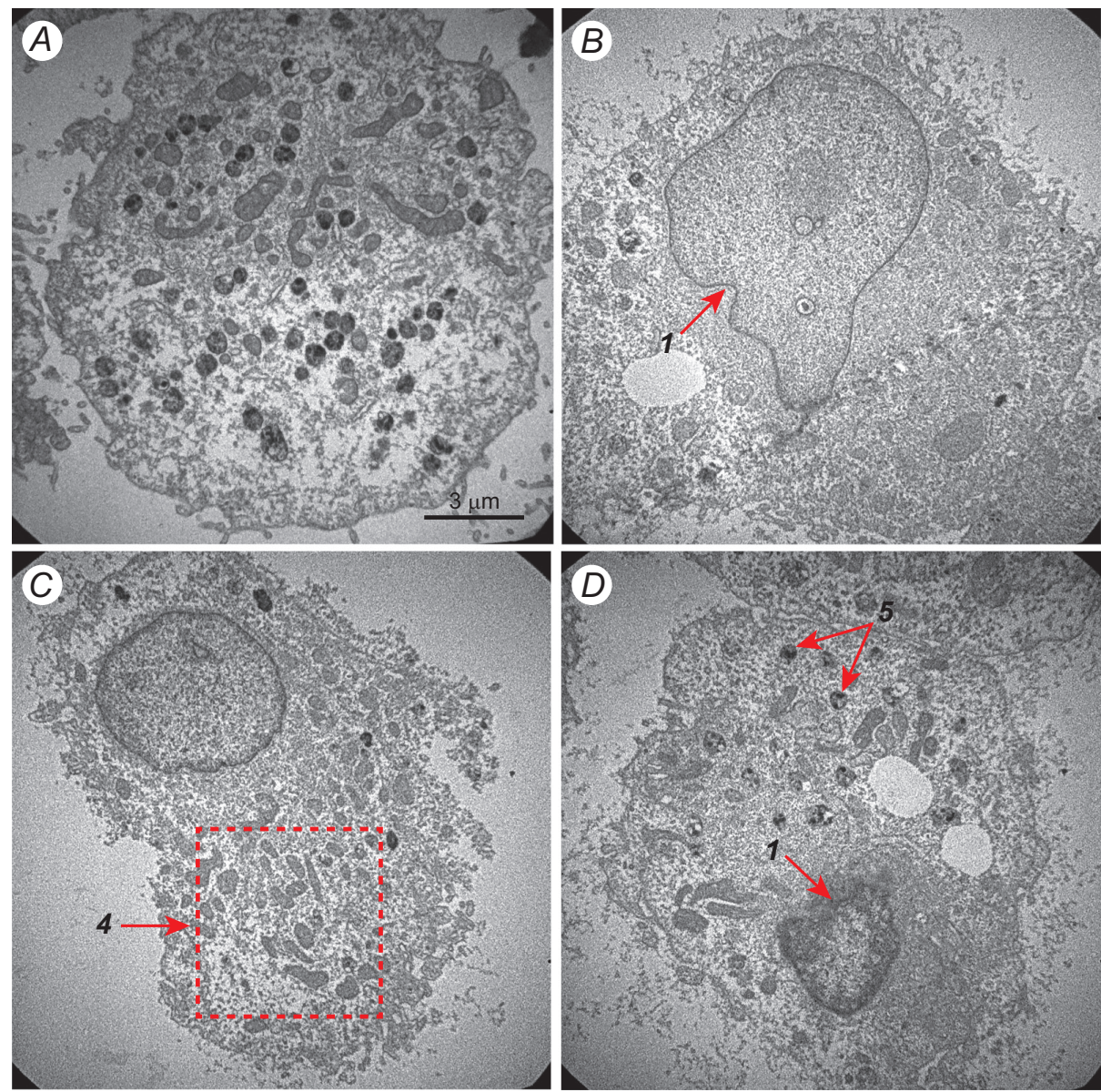

Fig. 3. Electronic microscopy of lymphoma NK/Ly cells under the action of the thiazole derivative in concentration of $50 \mu \mathrm{M}$. For further explanations, see in Fig. 1

Рис. 3. Електронна мікроскопія клітин лімфоми NK/Ly за дії похідного тіазолу в концентрації 50 мкM. Інші пояснення див. рис. 1

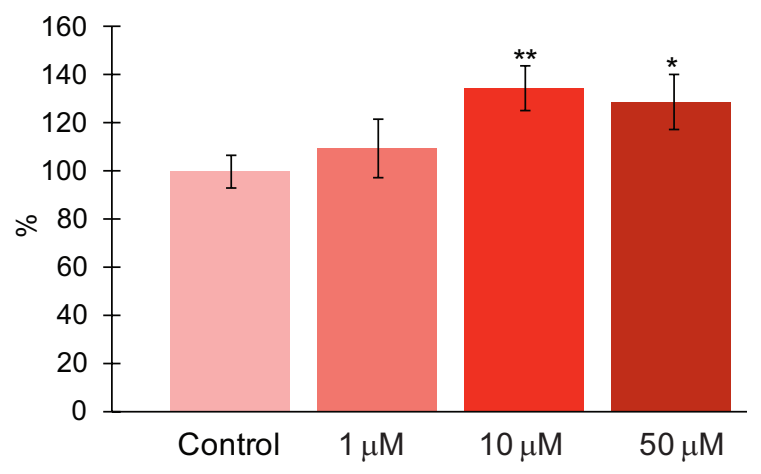

Fig. 4. Effects of the thiazole derivative at concentrations of $1,10,50 \mu \mathrm{M}$ on the activity of superoxide dismutase in the lymphoma cells. Control level of the enzyme activity was assumed to be $100 \% . M \pm m ; n=5 .{ }^{*}-$ $P<0.05 ;{ }^{* *}-P<0.01$

Рис. 4. Активність супероксиддисмутази у гомогенаті лімфоми за дії похідного тіазолу в концентраціях 1,10 , 50 мкМ. Контрольний рівень активності ферменту прийнятий за $100 \% . \mathrm{M} \pm \mathrm{m} ; \mathrm{n}=5 .{ }^{*}-P<0,05$; ** $-P<0,01$ 


\section{A quantitate analysis of electronic microscopy data of studying lymphoma cells under the effect of the thiazole derivative (TD) \\ Кількісний аналіз електронно-мікроскопічних фотографій клітин лімфоми за дії похідного тіазолу}

\begin{tabular}{|c|c|c|c|c|c|}
\hline No & Parameters & Control & $\mathrm{TD}, 10 \mu \mathrm{M}$ & $\mathrm{TD}, 50 \mu \mathrm{M}$ & Remarks \\
\hline \multicolumn{2}{|r|}{ Number of analyzed cells } & 12 & 12 & 9 & \\
\hline 1 & Cell area $(\%)$ & $100 \pm 26.3$ & $100 \pm 25.7$ & $100 \pm 13.0$ & $\begin{array}{l}\text { The control cells have mostly } \\
\text { oval shape. TD caused } \\
\text { shrinkage (apoptosis) or } \\
\text { swelling (nercrosis) of cells. }\end{array}$ \\
\hline 2 & Nucleus area in cell (\%) & $38.1 \pm 12.9$ & $32.8 \pm 9.75$ & $34.2 \pm 11.8$ & $\begin{array}{l}\text { In control cells large nuclei of } \\
\text { oval shape occupied } \sim 40 \% \text {. } \\
\text { TD led to a deformation and } \\
\text { a destruction of the nucleus. }\end{array}$ \\
\hline 3 & Cytoplasm area in cell (\%) & $61.9 \pm 20.6$ & $67.2 \pm 21.6$ & $65.8 \pm 9.56$ & \\
\hline 4 & Nuclear / cytoplasmic ratio & $0.69 \pm 0.36$ & $0.55 \pm 0.21$ & $0.53 \pm 0.23$ & $\begin{array}{l}\text { TD caused a decrease in } \\
\text { the ratio occur mostly due } \\
\text { to a nucleus decrease or } \\
\text { destruction. }\end{array}$ \\
\hline 5 & Lysosome area (\%) & $100 \pm 11.2$ & $127 \pm 7.2^{*}$ & $153 \pm 12.7^{\star *}$ & TD caused an increase \\
\hline 6 & $\begin{array}{l}\text { Number of lysosomes } \\
\text { (per cell) }\end{array}$ & $12 \pm 3$ & $11 \pm 2$ & $20 \pm 4$ & $\begin{array}{l}\text { in the number and area } \\
\text { of lysosomes. The visibly } \\
\text { bigger number of lysosomes } \\
\text { was observed in the treated } \\
\text { cells without nucleus. }\end{array}$ \\
\hline 7 & Mitochondria area (\%) & $100 \pm 8.6$ & $110 \pm 7.2$ & $94 \pm 3.9$ & Some a long-shape \\
\hline 8 & $\begin{array}{l}\text { Number of mitochondria } \\
\text { (per cell) }\end{array}$ & $22 \pm 4$ & $20 \pm 2$ & $26 \pm 3$ & $\begin{array}{l}\text { mitochondria appear under } \\
\text { TD influence. }\end{array}$ \\
\hline
\end{tabular}

Comments: In all experimental groups cellular area are taken as $100 \%$, while for lysosomes and mitochondria data only Control parameters is assumed to be $100 \%$. Cytoplasm area includes mitochondria and lysosomes. $\mathrm{M} \pm \mathrm{m}$. Statistically significant difference compared to Control: * $-P<0.05 ;{ }^{* *}-P<0.01$

Примітки: Площі клітин усіх трьох експериментальних груп прийняті за 100 \%, а для лізосом і мітохондрій за 100 \% прийнято тільки контрольні показники. Площа цитоплазми охоплює мітохондрії

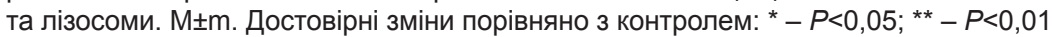

A large amount of $\mathrm{H}_{2} \mathrm{O}_{2}$, produced due to an increased SOD activity, is neutralized by CAT. CAT restores the Hydrogen peroxide to water [9]. Fig. 5 shows changes in the activity of CAT in the lymphoma cells under the action of TD. A control level of CAT activity was $0.23-0.35 \mathrm{nmol}$ of $\mathrm{H}_{2} \mathrm{O}_{2} / \mathrm{min} \times \mathrm{mg}$ of protein. It was established that the activity of the TD at a concentration of $10 \mu \mathrm{M}$ reduced by $15 \%$ the activity of CAT $(P<0.05)$.

In addition to CAT-activity, the neutralization of the $\mathrm{H}_{2} \mathrm{O}_{2}$ is also carried out by the GPO. This enzyme has a greater affinity for Hydrogen peroxide than CAT. Glutathionperoxidase function is more efficient at low concentrations of $\mathrm{H}_{2} \mathrm{O}_{2}$, whereas the CAT is more effective with high concentrations of the substrate $\left(\mathrm{H}_{2} \mathrm{O}_{2}\right)$ protecting the development of the oxidative stress [9]. 


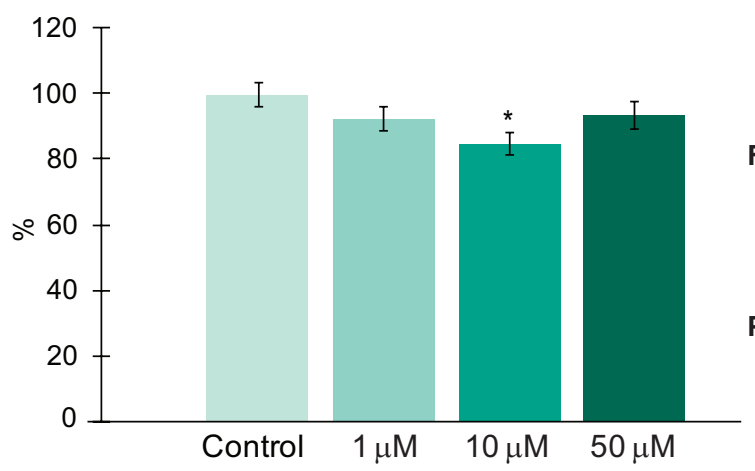

Fig. 5. Effect of the thiazole derivative at concentrations of $1,10,50 \mu \mathrm{M}$ on the activity of catalase in the lymphoma cells. The control level of the enzyme activity is assumed as $100 \% . M \pm m ; n=5 .{ }^{*}-P<0.05$

Рис. 5. Активність каталази у лімфомі за дії похідного тіазолу у концентраціях 1 , 10, 50 мкМ. Контрольний рівень активності ферменту прийнятий за $100 \%$. $\mathrm{M} \pm \mathrm{m} ; \mathrm{n}=5$. $^{*}-\mathrm{P}<0,05$

Fig. 6 shows changes in the activity of GPO under the action of the TD. Control level of the enzyme was $4.33-4.53 \mathrm{nmol} \mathrm{GSH} / \mathrm{min} \times \mathrm{mg}$ protein. It was defined that the activity of GPO was decreased under the action of TD at concentrations of 10 and $50 \mu \mathrm{M}$ on $29 \%(P<0.01)$ and $27 \%(P<0.05)$, respectively.

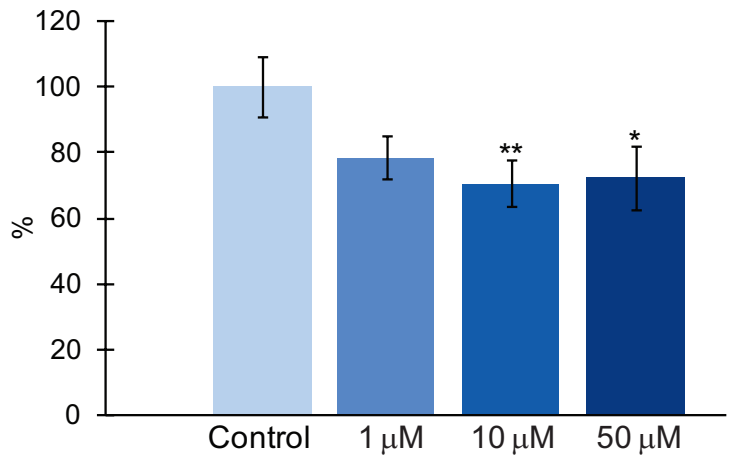

Fig. 6. Effect of the thiazole derivative at concentrations of $1,10,50 \mu \mathrm{M}$ on the activity of glutathion peroxidase in the lymphoma cells. The control level of the enzyme activity is assumed as $100 \%$. $\mathrm{M} \pm \mathrm{m} ; \mathrm{n}=5 .{ }^{*}-P<0.05 ;{ }^{* *}-P<0.01$

Рис. 6. Активність глутатіонпероксидази у лімфомі за дії похідного тіазолу у концентраціях 1, 10, 50 мкМ. Контрольний рівень активності фрерменту прийнятий за $100 \% . \mathrm{M} \pm \mathrm{m} ; \mathrm{n}=5 .{ }^{*}-P<0,05$; ** $-P<0,01$

TD action leads to an increase in SOD activity in the lymphoma, while TD reduces the activity of CAT and GPO that leads to accumulation of $\mathrm{H}_{2} \mathrm{O}_{2}$ in tumor cells. These effects are cytotoxic and cause DNA breaks, apoptosis, and reduce the intensity of glycolysis in tumor cells [9]. It was found that TD increased the level of primary products of lipid peroxidation and does not change the level of secondary products, such as, malonic dialdehyde [12]. It was established that the TD decrease the level of superoxide radicals. These results indicate that an increase in SOD activity might have a compensatory effect. The activity of antioxidant enzyme affect the level of primary and secondary products of lipid peroxidation that can be toxic to cancer cells. According to the obtained results, SOD, CAT, and GPO as key enzymes of the antioxidant defense, may be a target for antitumor drugs. Thus, it are assumed that such changes in the activity of the antioxidant enzymes by TD may be a part of the mechanism of increasing sensitivity of cancer cells to the antitumor agents.

Thus, the investigated TD at concentration of 10 and $50 \mu \mathrm{M}$ caused irreversible changes in the ultrastructure of lymphoma cells. The action of the substance led to a destruction of the plasma membrane, the deformation and destruction of the nucleus, an increase in the area and a number of lysosomes.

Thiazole derivatives are characterized by high lipophilicity due to the presence of a macrocycle ring in the molecular structure. This feature facilitates their penetration

ISSN 1996-4536 (print) •ISSN 2311-0783 (on-line) • Біологічні Студії / Studia Biologica • 2019 • Том 13/№1 • C. 51-60 
into the cell and, in turn, it determines intracellular targets [8]. Products of the lipoperoxidations and the antioxidant enzymes could be among these targets.

Earlier, it was shown that the effectiveness of the tested substance toward tumor cells is mediated by an increased amount of $\mathrm{H}_{2} \mathrm{O}_{2}$. We assumed that toxic effect of the thiazole derivative toward tumor cells, and their destructive changes might be due to the effect of substance on the activity of the antioxidant enzymes. Since the tested substance does not affect normal cells [1,13], we suggest that this thiazole derivative might be considered as a potential antitumor drug.

1. Finiuk N.S.,Hreniuh V.P., Ostapiuk Yu.V., Matiychuk V.S., Frolov D.A., Obushak M.D., Stoika R.S., Babsky A.M. Antineoplastic activity of novel thiazole derivatives. Biopolym. Cell, 2017; 33(2): 135-46.

[DOI: http://dx.doi.org/10.7124/bc.00094B; Google Scholar]

2. Finiuk N.S., Ostapiuk Yu.V., Hreniuh V.P. Shalai Ya.R., Matiychuk V.S., Obushak M.D., Stoika R.S., Babsky A.M. Evaluation of antiproliferative activity of pyrazolothiazolopyrimidine derivatives. Ukr. Biochem. J., 2018; 90(2): 16-23.

[DOI: https://doi.org/10.15407/ubj90.02.025; Google Scholar]

3. Hreniukh V., Lutsik M., Kulachkovsky O., Stoika R., Babsky A. Comparative characteristic of respiration parameters and oxidative phosphorylation in mitochondria of NK/Ly lymphoma and liver of mouse. Studia Biologica, 2015; 9(2): 39-50. (In Ukrainian)

[DOI: https://doi.org/10.30970/sbi.0902.414; Google Scholar]

4. Kaminskyy V., Kulachkovskyy O., Stoika R. A decisive role of mitochondria in defining rate and intensity of apoptosis induction by different alkaloids. 2008; Toxicol Lett., 2008; 177(3): 168-81.

5. Korolyuk M.A., Ivanova L.I., Mayorova I.H., Tokaryev V.Ye. Method for determination of catalase activity. Lab. Delo, 1988; 1: 16-9. (In Russian)

6. Kostyuk V.A., Potapovich A.I., Kovaleva Zn.V. A simple, sensitive assay for determination of superoxide dismutase activity based on reaction of quercetin oxidation. Problems of Medical Chemistry, 1990; 2: 88-91. (In Russian)

7. Lowry O.H., Rosebrough N.J., Farr A.L., Randall R.J. Protein measurement with the folin phenol reagent. J. Biol. Chem., 1951; 193: 265-75. [Google Scholar]

8. Mandzynets S.M., Kulachkovskii O.R., Bura M.V. Effect of avermectin on the ultrastructural characteristics of loach embryos. Cytol. Genet., 2011; 45(5): 318-23. (In Ukrainian) [DOI: http://dx.doi.org/10.3103/S0095452711050070, Google Scholar]

9. Menshchikova E.B., Lankin V.Z., Bondar N.K., Krugovykh N.F., Trufakin V.A. Oxidative stress. Prooxidants and antioxidants. Moscow: Slovo, 2006; 556 p. (In Russian) [Google Scholar]

10. Moin V.M. A simple and specific method for determining the activity of glutathione peroxidase in erythrocytes. Lab. Delo, 1986; 12: 124-6. (In Russian)

11. Narang A.S., Desai D.S. Anticancer Drug Development. Unique Aspects of Pharmaceutical Development. Pharmaceutical Perspectives of Cancer Therapeutics. Springer Science Business Media, 2009; 49-92.

[Google Scholar]

12. Shalai Ya.R., Mandzynets S.M., Hreniukh V.P., Finiuk N.S., Babsky A.M. Free-radical processes in NK/Ly lymphoma cells and hepatocytes under the effect of thiazole derivative. Bulletin of problems biology and medicin, 2018; 143(1): 234-8. (In Ukrainian) [DOI: http://dx.doi.org/10.29254/2077-4214-2018-1-2-143-234-238]

13. Shalai Ya.R., Mandzynets S.M., Finiuk N.S., Hreniukh V.P., Babsky A.M. Processes of lipoperoxidation and respiration of mitochondria in the rat liver under the action of thiazoles derivatives in vitro. Studia Biologica, 2018; 12(2): 35-44. (In Ukrainian) [DOI: https://doi.org/10.30970/sbi.1202.551, Google Scholar]

14. Turov K.V., Krupskaya T.V., Barvinchenko V.M. Antiradical properties of thiazole derivatives. influence on metabolic activity of yeast. Biotechnologia Acta, 2012; 5(3): 75-83. (In Ukrainian) [Google Scholar] 
15. Zhou C.H., Wang Y. Recent researches in triazole compounds as medicinal drugs. Curr. Med. Chem., 2012; 19(2): 239-80.

[PMID: 22320301; Google Scholar]

16. Zyn A., Bezkorovayny A., Harasym N., Kulachkovsky O., Sanagursky D. Morphological and ultrastructural changes of loach embryos during embryogenesis under the influence of sodium hypochlorite. Visnyk of the Lviv University. Series Blology, 2014; 67: 18-28. (In Ukrainian)

\title{
ВПЛИВ ПОХІДНОГО ТІАЗОЛУ НА КЛІТИННУ УЛЬТРАСТРУКТУРУ І СТАН АНТИОКСИДАНТНОЇ СИСТЕМИ У КЛІТИНАХ ЛІМФОМИ НЕМЕТ-КЕЛНЕРА
}

\author{
Я. Р. Шалай', М. В. Попович1, О. Р. Кулачковський1, \\ В. П. Гренюх ${ }^{1}$, С. М. Мандзинець ${ }^{1}$, Н. С. Фінюк ${ }^{1,2}$, А. М. Бабський \\ 1 Львівський національний університет імені Івана Франка \\ вул. Грушевського, 4, Львів 79005, Україна \\ e-mail:yarunash@gmail.com \\ ${ }^{2}$ Інститут біології клітини НАН України, вул. Драгоманова, 14/16, Львів 79005, Україна
}

Досліджено вплив новосинтезованого похідного тіазолу N-(5-бензил-1,3-тіазол2-іл)-3,5-диметил-1-бензофруран-2-карбоксаміду на ультраструктуру клітин і активність фрерментів антиоксидантної системи лімфоми Немет-Келнера in vitro. Раніше встановлено виражену цитотоксичну дію новосинтезованого похідного тіазолу на пухлинні клітини in vitro і не виявлено вираженої цитотоксичності цієї речовини щодо непухлинних клітин. Крім того, було досліджено, що знешкоджувачі активних форм Оксигену суттєво знижують цитотоксичний ефрект досліджуваної сполуки. Подальші експерименти на клітинах лімфоми виявили, що досліджувана речовина зумовлювала зниження рівня супероксидного радикалу. Метою цього дослідження було дослідити вплив N-(5-бензил-1,3-тіазол-2-іл)-3,5-диметил-1-бензофуран-2-карбоксаміду на ультраструктуру клітин і активність ферментів антиоксидантної системи лімфоми Немет-Келнера. На першому етапі роботи досліджено вплив похідного тіазолу на ультраструктуру клітин лімфоми. На підставі електронно-мікроскопічних досліджень встановлено, що контрольні клітини лімфоми мають характерну для пухлинних клітин форму: велике ядро, відносно менша кількість цитоплазми, специфрічні вип'ячування плазматичної мембрани. За дії похідного тіазолу у концентраціях 10 і 50 мкМ виявлено різні прояви цитотоксичності: деформація та дезінтеграція ядра, руйнування плазматичної мембрани, апоптичні та некротичні структурні зміни. На другому етапі досліджували вплив похідного тіазолу на активність ключових феерментів антиоксидантної системи клітин лімфоми. Досліджувана речовина у концентраціях 10 і 50 мкМ призводила до підвищення активності супероксиддисмутази, натомість знижувала активність каталази і глутатіонпероксидази, що може зумовлювати накопичення $\mathrm{H}_{2} \mathrm{O}_{2}$ у пухлинних клітинах. Отже, структурні зміни клітин лімфоми та цитотоксичний ефект похідного тіазолу ймовірно реалізовуються внаслідок порушення активності антиоксидантних ферментів. Результати роботи можуть бути використані для проведення подальших доклінічних досліджень похідного тіазолу як потенційного протипухлинного препарату.

Ключові слова: лімфома, похідні тіазолу, ультраструктура, антиоксидантна система, лізосоми

Одержано: 11.04 .2019

ISSN 1996-4536 (print) • ISSN 2311-0783 (on-line) • Біологічні Студії / Studia Biologica • 2019 • Том 13/№1 • С. 51-60 